\title{
Effect of uric acid on mitochondrial function and oxidative stress in hepatocytes
}

\author{
Y. Yang ${ }^{1}$, Y. Zhou ${ }^{2}$, S. Cheng', J.L. Sun ${ }^{1}$, H. Yao ${ }^{3}$ and L. Ma ${ }^{1}$ \\ ${ }^{1}$ School of Public Health, Xinjiang Medical University, Xinjiang, \\ Urumqi, China \\ ${ }^{2}$ School of Basic Medicine, Xinjiang Medical University, Xinjiang, \\ Urumqi, China \\ ${ }^{3}$ The First Affiliated Hospital of Xinjiang Medical University, \\ Xinjiang, Urumqi, China \\ Corresponding author: L. Ma \\ E-mail: maling3633@126.com
}

Genet. Mol. Res. 15 (2): gmr.15028644

Received March 23, 2016

Accepted April 11, 2016

Published June 24, 2016

DOI http://dx.doi.org/10.4238/gmr.15028644

\begin{abstract}
Here, we investigated the effect of uric acid (UA) on hepatocyte mitochondria. Hepatocytes cultured in vitro were treated with varying concentrations of UA. The change in apoptotic activity was detected by flow cytometry. The DNA damage index 8-hydroxy-deoxyguanosine $(8-\mathrm{OHdG})$ and mitochondrial function indices succinate dehydrogenase (SDH), cytochrome $\mathrm{C}$ oxidase $(\mathrm{CCO})$, and adenosine triphosphate (ATP) were detected by enzyme assays. Reactive oxygen species (ROS) accumulation was confirmed by a dichloro-dihydrofluorescein diacetate assay. We observed an increase in apoptotic activity, ROS accumulation, and 8-OHdG activity in hepatocytes treated with UA for extended periods, indicating DNA damage; specifically, we observed a significant increase in these activities 48, 72, and 96 $\mathrm{h}$ after UA addition, compared to those observed at $24 \mathrm{~h}(\mathrm{P}<0.05)$. Cells treated with $30 \mathrm{mg} / \mathrm{dL}$ UA for $96 \mathrm{~h}$ showed a peak in apoptotic activity. We also observed a significant decrease in ATP, SDH, and $\mathrm{CCO}$ activities with the increase in uric acid concentration over time.
\end{abstract}


Cells treated with $30 \mathrm{mg} / \mathrm{dL}$ UA for $96 \mathrm{~h}$ showed the highest ATP levels, while SDH and CCO activities at 48, 72, and $96 \mathrm{~h}$ post-UA treatment were significantly lower than those at $24 \mathrm{~h}(\mathrm{P}<0.01)$. Moreover, cells treated with $30 \mathrm{mg} / \mathrm{dL}$ UA showed a $0.02 \pm 0.02$ and $0.15 \pm 0.01 \mu \mathrm{mol} /$ $\mathrm{mg} / \mathrm{min}$ decrease in SDH and CCO levels after $72 \mathrm{~h}$. Therefore, we concluded that high concentrations of UA may induce oxidative stress in hepatocyte mitochondria, increasing ROS production and ultimately resulting in mitochondrial damage.

Key words: Uric acid; Mitochondrial damage; Oxidative stress; Cell apoptosis; DNA damage

\section{INTRODUCTION}

Human infants produce uric acid (UA), a major endogenous water-soluble antioxidant, as an end-product of purine metabolism. Previous studies have shown a close association between UA production and non-alcoholic fatty liver disease ( $\mathrm{Li}$ et al., 2009; Sirota et al., 2013), liver cancer (Port et al., 2014), and other liver diseases. Hepatocytes are the primary sites of UA generation. Aberrant UA metabolism can cause hepatocyte injury by inducing oxidative stress. The mitochondria is the primary organelle involved in restoring oxygen molecules, and is an important source of reactive oxygen species (ROS) (Kuhlbrandt, 2015). Purine metabolism occurs predominantly in hepatocytes, which contain 500-1000 mitochondria; therefore, these cells play a major role in oxidative stress. A previous study reported that mitochondrial stimulation resulted in hepatocyte damage, which, in turn, caused oxidative stress in hyperuricemic rats (Lanaspa et al., 2012). Another study conducted in a UA-induced non-alcoholic fatty liver showed that uric acid induced ROS production in the mitochondria, which led to increased fat synthesis and triglyceride accumulation (Choi et al., 2014). However, the exact mechanism of the effect of UA on hepatocyte mitochondrial function remains unclear. In this study, we investigated the effect of UA on hepatocyte mitochondrial function and oxidative stress in vitro.

\section{MATERIAL AND METHODS}

\section{Reagents and antibodies}

Hepatocytes (L-02) were purchased from KeyGEN Biotech Development Co., Ltd. (Nanjing, China). Culture media (Dulbecco's modified Eagle's medium; DMEM), phosphatebuffered saline (PBS), and fetal bovine serum (FBS) were obtained from Gibco (Grand Island, NY, USA). Trypsin (2.5\%) and double antibody were also purchased from Gibco. Uric acid powder was obtained from Sigma-Aldrich (St. Louis, MO, USA), while the Mitochondrial Extraction Kit was purchased from Beijing Solarbio Science and Technology (Beijing, China). Commercial kits for the detection of succinate dehydrogenase (SDH) and cytochrome $\mathrm{C}$ oxidase (CCO) were purchased from GenMed Medical Science and Technology (Shanghai, China). The human 8-hydroxy-deoxyguanosine (8-OHdG) ELISA kit was purchased from Bio-Swamp Immunoassay R\&D Center (Guangzhou, China), while commercial kits for the measurement of ATP and ROS, and the BCA protein assay kit, were purchased from Nanjing 
Jiancheng Bioengineering Institute (Nanjing, China). Fluorescein isothiocyanate (FITC)labeled Annexin V and propidium iodide were obtained from BD Biosciences (Franklin Lakes, NJ, USA).

\section{Cell culture and chemical treatment}

The hepatocytes were maintained in DMEM supplemented with $10 \%$ FBS in a 5\% $\mathrm{CO}_{2}$ incubator at $37^{\circ} \mathrm{C}$ (Wang et al., 2015). At a confluence rate of $80 \%$, the cells were treated with different concentrations of UA $(5,10,20$, and $30 \mathrm{mg} / \mathrm{dL})$ and cultured for $24,48,72$, and $96 \mathrm{~h}$. The control group was treated with $0 \mathrm{mg} / \mathrm{dL}$ UA. The cells were subsequently harvested and analyzed.

\section{Detection of apoptosis in hepatocytes by flow cytometry}

The apoptotic frequency in treated hepatocytes was measured by an Annexin V-FITC/ propidium iodide double-staining method (Gao et al., 2015). Briefly, cells treated with UA for $24,48,72$, and $96 \mathrm{~h}$ were collected and stained with binding buffer containing $10 \mu \mathrm{L}$ propidium iodide and $5 \mu \mathrm{L}$ Annexin $\mathrm{V}$ in the dark at room temperature for $15 \mathrm{~min}$. The stained cells were then analyzed with a FACSort flow cytometer (BD Biosciences). The percentage of cells in each phase of the cell cycle was calculated using the ModFit software (Verity Software House, Topsham, ME, USA).

\section{Intracellular ROS analysis}

Cells in the logarithmic phase of growth were added to a 6-well plate at a density of $1 \times 10^{5}$ cells/well. Hepatocytes at a confluence rate of $\sim 70 \%$ were treated with varying concentrations of UA [untreated cells $(0 \mathrm{mg} / \mathrm{dL})$ were used as controls] for $24,48,72$, and $96 \mathrm{~h}$. The cells were then incubated with dichloro-dihydro-fluorescein diacetate at a final concentration of $40 \mu \mathrm{M}$ for $40 \mathrm{~min}$, rinsed with PBS, and observed under a fluorescence microscope (10X) (Cao et al., 2015). The fluorescence intensity was determined using the ImageJ image analysis software (NIH, Bethesda, MD, USA).

\section{Measurement of mitochondrial function}

The mitochondria of hepatocytes treated with varying concentrations of UA for 24 , 48,72 , and $96 \mathrm{~h}$ were isolated and their SDH, CCO, and ATP activities were determined using their corresponding assay kits, according to the manufacturer protocols; 8-OHdG expression in the mitochondria was also determined using a commercial kit. Protein concentrations were determined using the BCA protein assay kit. The SDH and $\mathrm{CCO}$ activities were expressed as $\mu \mathrm{M} / \mathrm{mg}$ protein/min, while the ATP and $8-\mathrm{OHdG}$ activities were presented as $\mathrm{U} / \mathrm{mg}$ protein and $\mathrm{pg} / \mathrm{mg}$ protein, respectively.

\section{Statistical analysis}

The obtained data were statistically analyzed using SPSS 17.0 (SPSS, Inc., Chicago, IL, USA). Data are reported as means \pm standard deviation of three independent experiments, 
and were analyzed by one-way analysis of variance (ANOVA). The results were considered to be statistically significant at $\mathrm{P}<0.05$ and highly significant at $\mathrm{P}<0.01$.

\section{RESULTS}

\section{Effect of UA on apoptosis in hepatocytes}

First, we investigated UA-induced apoptosis in L-02 cells. We observed an increase in the apoptosis rate in hepatocytes with the increase in UA concentration and treatment time (Figure 1); that is, the highest apoptosis rate was observed in cells treated with $30 \mathrm{mg} / \mathrm{dL} \mathrm{UA}$ for $96 \mathrm{~h}$ (Figure 2). Cells treated with 20 and $30 \mathrm{mg} / \mathrm{dL}$ UA for $24 \mathrm{~h}$ showed apoptosis rates of 5.10 and $6.50 \%$, which were significantly higher than the rate shown by cells in the control group $(\mathrm{P}<0.01)$. Similarly, cells treated with 5, 10, 20, and $30 \mathrm{mg} / \mathrm{dL} \mathrm{UA}$ for 48, 72, and $96 \mathrm{~h}$ showed significant increase in apoptotic rates $(4.93,6.03,6.50$, and $7.13 \% ; 9.07,10.66,14.73$, and $20.77 \%$; and $11.67,15.00,29.33$, and $35.47 \%$, respectively) $(\mathrm{P}<0.01)$. We also observed a progressive increase in the apoptotic rates in cells treated with 5 and $10 \mathrm{mg} / \mathrm{dL}$ UA for 24,48 , 72, and $96 \mathrm{~h}(\mathrm{P}<0.01)$, while cells treated with 20 and $30 \mathrm{mg} / \mathrm{dL} \mathrm{UA}$ for 72 and $96 \mathrm{~h}$ showed significantly higher apoptotic rates than those treated for $24 \mathrm{~h}(\mathrm{P}<0.01)$.

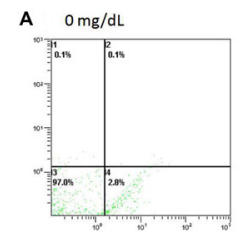

B $\quad 0 \mathrm{mg} / \mathrm{dL}$

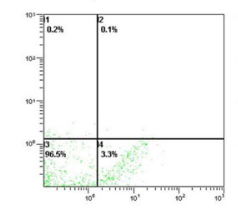

$-$
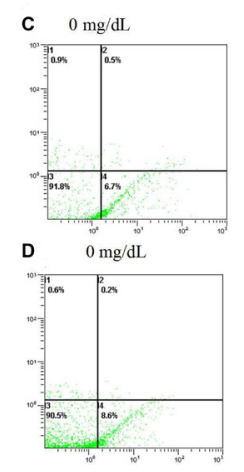

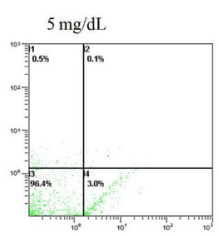

$5 \mathrm{mg} / \mathrm{dL}$
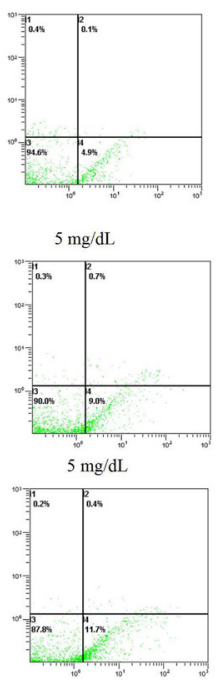

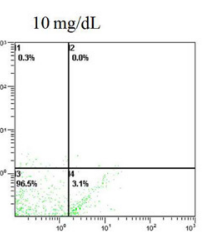

$10 \mathrm{mg} / \mathrm{dL}$
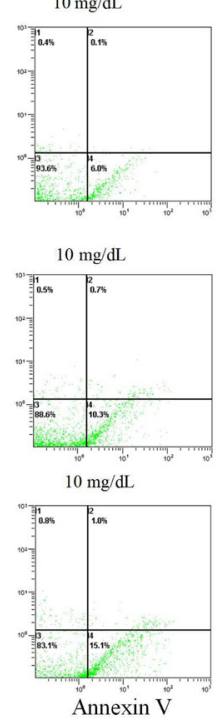
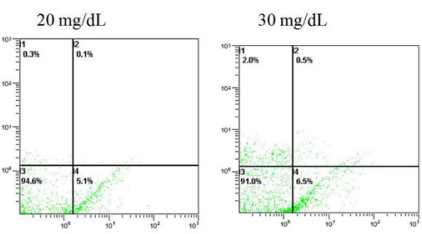

$20 \mathrm{mg} / \mathrm{dL}$

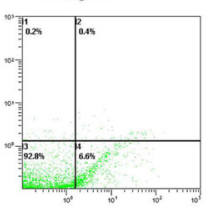

$30 \mathrm{mg} / \mathrm{dL}$
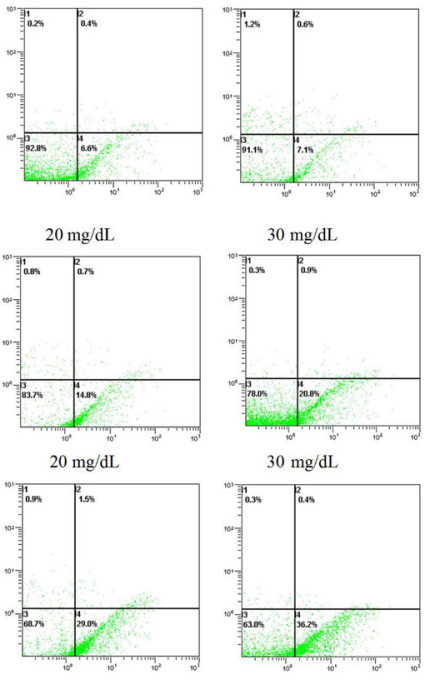

Figure 1. Cells treated with UA [0 (control), 5, 10, 20, and $30 \mathrm{mg} / \mathrm{dL}]$. A. B. C. D. UA treatment for 24, 48, 72, and $96 \mathrm{~h}$, respectively. The horizontal and vertical axes represent Annexin V and propidium iodide staining, respectively. 


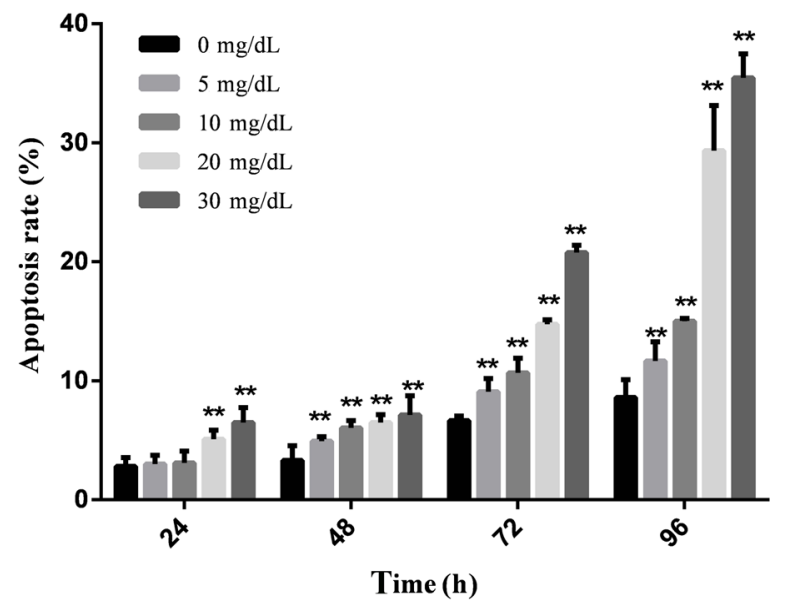

Figure 2. Effect of different levels of uric acid on apoptosis in hepatocytes. Hepatocytes were treated with UA [0 (control), 5, 10, 20, and $30 \mathrm{mg} / \mathrm{dL}$ ] for $24,48,72$, and $96 \mathrm{~h}$. The results are representative of three independent experiments (means $\pm \mathrm{SD}$ ). The asterisk symbols denote significant differences between the ATP, SDH, and CCO levels in UA-treated groups and the control group: $* \mathrm{P}<0.05$ and $* * \mathrm{P}<0.01$.

\section{Effect of UA on ROS activity in hepatocytes}

Next, we investigated the possible effect of UA on ROS production in L-02 cells. The fluorescence microscopy images showed an increase in fluorescence (related to ROS activity) corresponding to the increase in UA concentrations and treatment time; consequently, cells treated with $30 \mathrm{mg} / \mathrm{dL}$ UA for $96 \mathrm{~h}$ showed the highest fluorescent signals (Figure 3). The mean fluorescence value determined using Image J showed a similar trend; ROS production increased with the increase in UA concentration and time, and peaked at $96 \mathrm{~h}$ in cells treated with $30 \mathrm{mg} / \mathrm{dL}$ (Figure 4).

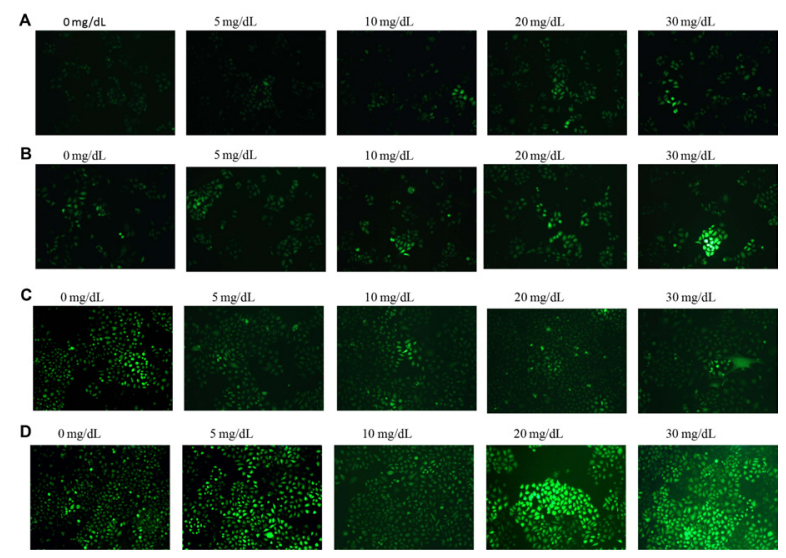

Figure 3. Measurement of ROS. Representative fluorescence images (original magnification 10X) of ROS production in cells treated with different UA concentrations [0 (control), 5, 10, 20, and $30 \mathrm{mg} / \mathrm{dL}$ ] and for different periods $(24,48,72$, and 96 h). A. B. C. D. UA treatment for 24, 48, 72, and 96 h, respectively. Cells producing ROS were stained green. 


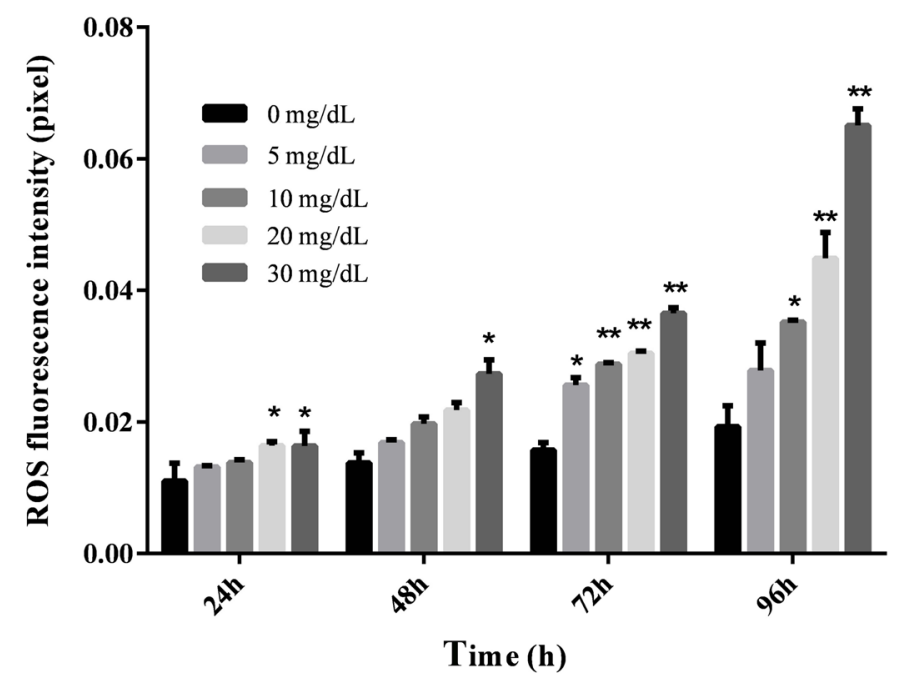

Figure 4. Mean value of ROS fluorescence analyzed using the Image $J$ software. The cells were treated with different concentrations of UA [0 (control), 5, 10, 20, and $30 \mathrm{mg} / \mathrm{dL}$ ] for $24,48,72$, and $96 \mathrm{~h}$. The results are representative of three independent experiments (means $\pm \mathrm{SD}$ ). The asterisk symbols denote significant differences between the ATP, SDH, and CCO levels in UA-treated groups and the control group: ${ }^{*} \mathrm{P}<0.05$ and $* * \mathrm{P}<0.01$.

We observed a significant increase in the mean fluorescence value of ROS in cells treated with 20 and $30 \mathrm{mg} / \mathrm{dL}$ UA compared to those treated with 5 and $10 \mathrm{mg} / \mathrm{dL}$ UA for 24 $\mathrm{h}(\mathrm{P}<0.05)$. On the other hand, cells treated with $30 \mathrm{mg} / \mathrm{dL} \mathrm{UA}$ for $72 \mathrm{~h}$ showed a significant increase in ROS production compared to those treated with 5,10 , and $20 \mathrm{mg} / \mathrm{dL} \mathrm{UA}(\mathrm{P}<0.01)$. Cells treated with $30 \mathrm{mg} / \mathrm{dL}$ UA for $96 \mathrm{~h}$ also showed a significant increase in ROS production compared to those treated with 5,10 , and $20 \mathrm{mg} / \mathrm{dL}(\mathrm{P}<0.05)$. ROS levels were significantly higher in cells treated with $20 \mathrm{mg} / \mathrm{dL}$ UA for 72 and $96 \mathrm{~h}$, compared to those treated with the same amount of UA for 24 and $48 \mathrm{~h}(\mathrm{P}<0.01)$. Additionally, ROS production increased progressively in cells treated with $10 \mathrm{mg} / \mathrm{dL} \mathrm{UA}$ for $24,48,72$, and $96 \mathrm{~h}(\mathrm{P}<0.01)$. On the other hand, cells treated with $20 \mathrm{mg} / \mathrm{dL}$ UA for $72 \mathrm{~h}$ showed significantly higher ROS levels than those treated for $24 \mathrm{~h}(\mathrm{P}<0.05)$, while cells treated for $96 \mathrm{~h}$ showed the highest increase compared to cells treated for shorter time periods $(\mathrm{P}<0.01)$. Cells treated with $30 \mathrm{mg} / \mathrm{dL}$ UA for $96 \mathrm{~h}$ showed a maximum increase in ROS (0.024 pixels).

\section{Effect of uric acid on DNA damage in hepatocytes}

8-OHdG levels were measured to determine the possible effect of UA on oxidative DNA damage in L- 02 cells. The cells were treated with varying concentrations of UA $(0=$ control, 5 , 10, 20, and $30 \mathrm{mg} / \mathrm{dL}$ ) for 24, 48, 72, and $96 \mathrm{~h}$. As shown in Figure 5, we observed a significant increase in 8-OHdG levels with the increase in UA concentrations and treatment times. Specifically, cells treated with $30 \mathrm{mg} / \mathrm{dL}$ UA for 48,72 , and $96 \mathrm{~h}$ showed the most significant increase in 8-OHdG levels $(\mathrm{P}<0.01)$. Cells treated with 20 and $30 \mathrm{mg} / \mathrm{dL}$ for 24 and $96 \mathrm{~h}$ showed a significant increase in 8-OHdG levels, compared to cells treated with $5 \mathrm{mg} / \mathrm{dL} \mathrm{UA}(\mathrm{P}<0.01)$. We also observed a progressive and significant increase in 8-OHdG levels in cells treated with 5, 10,20 , and $30 \mathrm{mg} / \mathrm{dL}$ UA for 48 and $72 \mathrm{~h}(\mathrm{P}<0.01)$. At $96 \mathrm{~h}$, the 8-OHdG levels in cells treated 
with 20 and $30 \mathrm{mg} / \mathrm{dL}$ UA were $0.52 \pm 0.21$ and $1.03 \pm 0.44 \mathrm{pg} / \mathrm{mg}$, which were significantly increased compared to the level seen in cells treated with $5 \mathrm{mg} / \mathrm{dL} \mathrm{UA}(0.24 \pm 0.18 \mathrm{pg} / \mathrm{mg})(\mathrm{P}<$ 0.01 ). Additionally, cells treated with $5 \mathrm{mg} / \mathrm{dL}$ UA for $96 \mathrm{~h}$ showed significantly higher $8-\mathrm{OHdG}$ levels compared to those treated for 24,48 , and $72 \mathrm{~h}(\mathrm{P}<0.01)$. On the other hand, 8-OHdG levels increased progressively in cells treated with 10 and $30 \mathrm{mg} / \mathrm{dL}$ UA for 24, 48, 72, and 96 $\mathrm{h}(\mathrm{P}<0.01$ for all $)$, while those treated with $20 \mathrm{mg} / \mathrm{dL}$ UA showed higher concentrations of 8 -OHdG levels at 72 and $96 \mathrm{~h}$ compared to those at 24 and $48 \mathrm{~h}(\mathrm{P}<0.01)$. Cells treated with 30 $\mathrm{mg} / \mathrm{dL}$ UA for $96 \mathrm{~h}$ showed the highest level of $8-\mathrm{OHdG}(1.46 \pm 0.03 \mathrm{pg} / \mathrm{mg})$.

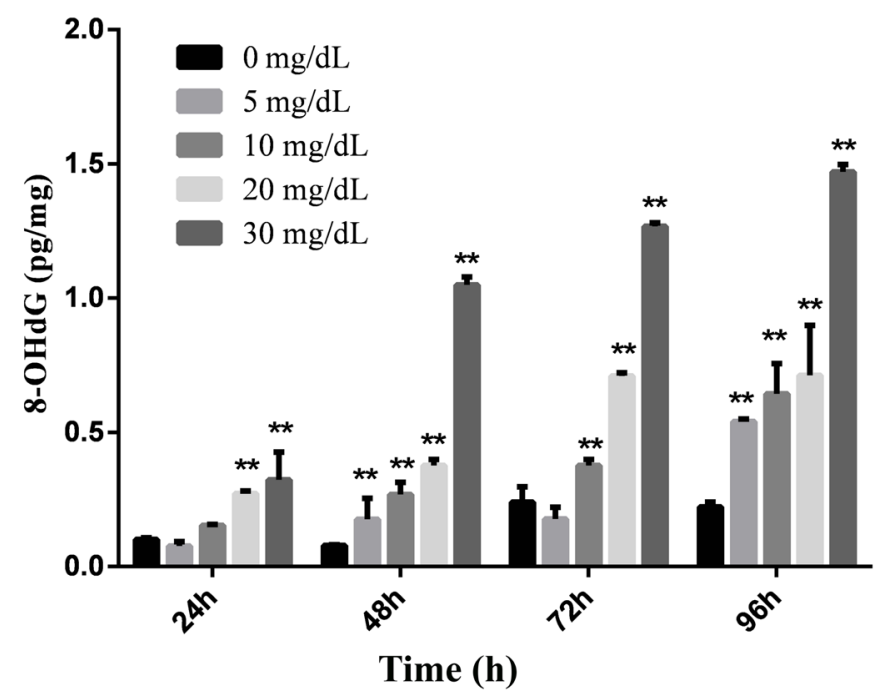

Figure 5. 8-OHdG content determined using the 8-OHdG ELISA kit. The cells were treated with different concentrations of UA [0 (control), 5, 10, 20, and $30 \mathrm{mg} / \mathrm{dL}]$ for 24, 48, 72, and $96 \mathrm{~h}$. The results are representative of three independent experiments (means $\pm \mathrm{SD}$ ). The asterisk symbols denote significant differences between the ATP, SDH, and CCO levels in UA-treated groups and the control group: $* \mathrm{P}<0.05$ and $* * \mathrm{P}<0.01$.

\section{Effect of UA on mitochondrial function in hepatocytes}

UA induced a decrease in the secretion of ATP, SDH, and CCO (Table 1) in hepatocytes. Cells treated with 10,20 , and $30 \mathrm{mg} / \mathrm{dL}$ UA for $24 \mathrm{~h}$ showed a highly significant decrease in ATP activity compared to those treated with $5 \mathrm{mg} / \mathrm{dL}$ UA for the same period of time $(\mathrm{P}<$ 0.01 ); treatment with $30 \mathrm{mg} / \mathrm{dL}$ UA induced a highly significant decrease in ATP compared to the $10-$ and $20-\mathrm{mg} / \mathrm{dL}$ UA treatment $(\mathrm{P}<0.05)$. On the other hand, cells treated with 10 , 20 , and $30 \mathrm{mg} / \mathrm{dL}$ UA for $48 \mathrm{~h}$ showed a significant decrease in ATP levels compared to those treated with $5 \mathrm{mg} / \mathrm{dL}$ UA $(\mathrm{P}<0.05)$; cells in the $30-\mathrm{mg} / \mathrm{dL}$ UA $(48 \mathrm{~h})$ group showed a significant decrease in ATP activity compared to those in the $10-\mathrm{mg} / \mathrm{dL}$ UA group $(\mathrm{P}<0.05)$. Cells treated with 20 and $30 \mathrm{mg} / \mathrm{dL}$ UA for $72 \mathrm{~h}$ showed lower levels of ATP compared to those treated with 5 and $10 \mathrm{mg} / \mathrm{dL} \mathrm{UA}(\mathrm{P}<0.01)$. This decrease was more significant in the $30-\mathrm{mg} /$ dL UA group compared to that in the $20-\mathrm{mg} / \mathrm{dL}$ UA group $(\mathrm{P}<0.05)$. At $96 \mathrm{~h}$, we observed a decrease in ATP activities in all groups of cells, excluding the $20-$ and $30-\mathrm{mg} / \mathrm{dL}$ groups $(\mathrm{P}<$ $0.05)$. Therefore, we observed that UA treatment led to a significant decrease in ATP activity ( $P$ $<0.01$ ). Cells treated with $5 \mathrm{mg} / \mathrm{dL}$ UA showed a significant decrease in ATP activity at all time 
points $(\mathrm{P}<0.01)$, while those treated with 10 and $20 \mathrm{mg} / \mathrm{dL}$ UA for 48, 72, and 96 h showed a significant downregulation in ATP levels compared to the $24-\mathrm{h}$ group $(\mathrm{P}<0.01)$. We observed a significant decrease in ATP levels in cells treated for $96 \mathrm{~h}$ compared to that in cells treated for 48 and $72 \mathrm{~h}(\mathrm{P}<0.01)$. Cells treated with $30 \mathrm{mg} / \mathrm{dL}$ UA for 48, 72, and $96 \mathrm{~h}$ showed a significant decrease in ATP activity compared to those treated for $24 \mathrm{~h}(\mathrm{P}<0.01)$. Cells treated for $96 \mathrm{~h}$ with $30 \mathrm{mg} / \mathrm{dL}$ UA showed the least amount of ATP activity, at $0.05 \pm 0.01 \mathrm{U} / \mathrm{mg}$.

Table 1. Effects of uric acid (UA) on mitochondrial function in L-02 cells.

\begin{tabular}{l|c|c|c|c|c|c}
\hline \multirow{2}{*}{ Target } & Time $(\mathrm{h})$ & Control group & \multicolumn{4}{|c}{ Uric acid level } \\
\cline { 3 - 7 } & & & $5 \mathrm{mg} / \mathrm{dL}$ & $10 \mathrm{mg} / \mathrm{dL}$ & $20 \mathrm{mg} / \mathrm{dL}$ & $30 \mathrm{mg} / \mathrm{dL}$ \\
\hline \multirow{3}{*}{ ATP $(\mathrm{U} / \mathrm{mg})$} & 24 & $1.10 \pm 0.08$ & $1.24 \pm 0.02^{*}$ & $0.88 \pm 0.03^{* *}$ & $0.88 \pm 0.03^{* *}$ & $0.72 \pm 0.21^{* *}$ \\
\cline { 2 - 7 } & 48 & $0.46 \pm 0.42$ & $0.64 \pm 0.02$ & $0.38 \pm 0.04$ & $0.38 \pm 0.04$ & $0.13 \pm 0.06^{*}$ \\
\cline { 2 - 7 } & 72 & $0.30 \pm 0.02$ & $0.35 \pm 0.06$ & $0.35 \pm 0.04$ & $0.22 \pm 0.12^{*}$ & $0.12 \pm 0.06^{* *}$ \\
\cline { 2 - 7 } & 96 & $0.27 \pm 0.04$ & $0.27 \pm 0.04$ & $0.18 \pm 0.03^{* *}$ & $0.09 \pm 0.01^{* *}$ & $0.05 \pm 0.01^{* *}$ \\
\hline \multirow{3}{*}{$\mathrm{SDH}(\mu \mathrm{mol} / \mathrm{mg} / \mathrm{min})$} & 24 & $0.39 \pm 0.02$ & $0.58 \pm 0.00^{* *}$ & $0.26 \pm 0.03^{* *}$ & $0.10 \pm 0.03^{* *}$ & $0.29 \pm 0.18^{* *}$ \\
\cline { 2 - 7 } & 48 & $0.21 \pm 0.26$ & $0.36 \pm 0.24$ & $0.15 \pm 0.02$ & $0.16 \pm 0.02$ & $0.04 \pm 0.03$ \\
\cline { 2 - 7 } & 72 & $0.13 \pm 0.00$ & $0.30 \pm 0.02^{* *}$ & $0.06 \pm 0.03^{*}$ & $0.07 \pm 0.04^{*}$ & $0.02 \pm 0.02^{* *}$ \\
\cline { 2 - 7 } & 96 & $0.09 \pm 0.01$ & $0.09 \pm 0.02$ & $0.08 \pm 0.05^{*}$ & $0.03 \pm 0.03^{*}$ & $0.03 \pm 0.02$ \\
\hline \multirow{3}{*}{$\mathrm{CCO}(\mu \mathrm{mol} / \mathrm{mg} / \mathrm{min})$} & 24 & $2.04 \pm 0.33$ & $1.67 \pm 0.10$ & $0.74 \pm 0.03^{* *}$ & $0.48 \pm 0.45^{* *}$ & $0.48 \pm 0.45^{* *}$ \\
\cline { 2 - 7 } & 48 & $0.96 \pm 0.72$ & $0.59 \pm 0.11$ & $0.40 \pm 0.02^{*}$ & $0.26 \pm 0.11^{*}$ & $0.19 \pm 0.18^{* *}$ \\
\cline { 2 - 7 } & 72 & $0.77 \pm 0.40$ & $0.31 \pm 0.18$ & $0.40 \pm 0.04^{* *}$ & $0.24 \pm 0.10^{*}$ & $0.15 \pm 0.00^{* *}$ \\
\cline { 2 - 7 } & 96 & $0.34 \pm 0.17$ & $0.27 \pm 0.20$ & $0.31 \pm 0.14$ & $0.27 \pm 0.13$ & $0.18 \pm 0.13$ \\
\hline
\end{tabular}

ATP, SDH, and CCO levels were assessed using commercial kits. The cells were treated with UA [0 (control], 5 , 10,20 , and $30 \mathrm{mg} / \mathrm{dL}$ ) for 24, 48, 72, and $96 \mathrm{~h}$. Results are representative of three independent experiments (means $\pm \mathrm{SD}$ ). The asterisk symbols denote significant differences between the ATP, SDH, and CCO levels in UA-treated groups and the control group: $* \mathrm{P}<0.05$ and $* * \mathrm{P}<0.01$.

We observed a significant decrease in SDH activity in cells treated with 20 and $30 \mathrm{mg} /$ dL UA for $24 \mathrm{~h}$ compared to those treated with 5 and $10 \mathrm{mg} / \mathrm{dL} \mathrm{UA}(\mathrm{P}<0.01)$. Cells treated with $30 \mathrm{mg} / \mathrm{dL}$ for $48 \mathrm{~h}$ showed a considerable decrease in SDH activity compared to those treated with $5 \mathrm{mg} / \mathrm{dL}$ for the same period of time $(\mathrm{P}<0.05)$. At $72 \mathrm{~h}$, all UA groups excluding the 10- and 20-mg/dL UA groups displayed a significant decrease in SDH activity $(\mathrm{P}<0.05)$. Similarly, at $96 \mathrm{~h}$, we observed a significant decrease in SDH levels in cells treated with 20 and $30 \mathrm{mg} / \mathrm{dL}$ UA compared to those treated with 5 and $10 \mathrm{mg} / \mathrm{dL} \mathrm{UA}(\mathrm{P}<0.05)$. Cells treated with $5 \mathrm{mg} / \mathrm{dL}$ for 72 and $96 \mathrm{~h}$ showed a significant decrease in SDH levels compared to the $24 \mathrm{~h}$ treatment group $(\mathrm{P}<0.05)$; moreover, the 96-h group showed lower SDH activity than the 48- and 72-h treatment groups $(\mathrm{P}<0.05)$. Cells treated with $10 \mathrm{mg} / \mathrm{dL}$ UA of $48 \mathrm{~h}$ showed a significant decrease in SDH compared to those treated for $24 \mathrm{~h}(\mathrm{P}<0.05)$; additionally, UA treatment for 72 and $96 \mathrm{~h}$ induced a significant decrease in SDH compared to treatment for 24 and $48 \mathrm{~h}(\mathrm{P}<0.01)$. Cells treated with $20 \mathrm{mg} / \mathrm{dL} \mathrm{UA}$ for 48, 72, and $96 \mathrm{~h}$ showed a significant decrease in SDH activity compared to those treated for $24 \mathrm{~h}(\mathrm{P}<0.01)$. Moreover, the $72-$ and 96-h treatment groups showed a significant decrease in SDH levels compared to the 48-h treatment group $(\mathrm{P}<0.01)$. Cells treated with $30 \mathrm{mg} / \mathrm{dL}$ UA for 48, 72, and $96 \mathrm{~h}$ showed a significant decrease in SDH compared to those treated for $24 \mathrm{~h}(\mathrm{P}<0.01)$. Finally, cells treated with $30 \mathrm{mg} / \mathrm{dL}$ UA for $72 \mathrm{~h}$ showed the lowest amount of SDH $(0.02 \pm 0.02 \mu \mathrm{mol} / \mathrm{mg} / \mathrm{min})$.

Cells treated with 10, 20, and $30 \mathrm{mg} / \mathrm{dL}$ UA for $24 \mathrm{~h}$ showed a significant decrease in CCO compared to those treated with $5 \mathrm{mg} / \mathrm{dL}$ UA $(\mathrm{P}<0.01)$. Cells treated with $5 \mathrm{mg} / \mathrm{dL}$ UA for 48, 72, and $96 \mathrm{~h}$ also showed a significant decrease in CCO compared to those treated for $24 \mathrm{~h}(\mathrm{P}<0.01)$; treatment for 96 and $72 \mathrm{~h}$ induced a highly significant decrease, compared to the 48-h treatment $(\mathrm{P}<0.05)$. Cells treated with $10 \mathrm{mg} / \mathrm{dL}$ UA for 48, 72, and $96 \mathrm{~h}$ also showed a significant decrease in CCO compared to those treated for $24 \mathrm{~h}(\mathrm{P}<0.01)$. Cells treated with $30 \mathrm{mg} / \mathrm{dL}$ UA for $72 \mathrm{~h}$ showed the lowest CCO activity $(0.15 \pm 0.01 \mu \mathrm{mol} / \mathrm{mg} / \mathrm{min})$. 


\section{DISCUSSION}

Data obtained from experimental and clinical studies indicated that UA plays a dual role as an anti-oxidant (Glantzounis et al., 2005) and pro-oxidant (Zhang et al., 2015) in hepatocytes. Previous studies have shown that UA exerts a detrimental effect as a pro-oxidant in cultured cells and in an animal model of hyperuricemia (Sautin et al., 2007; Kang and Ha, 2014). Preliminary experiments, wherein the cell viability was detected using an MTT assay, indicated that hepatocyte viability increased with the increase in UA concentration over time; this showed that UA does not suppress the growth and propagation of hepatocytes, and does not induce cell necrosis. However, microscopic analyses revealed that high concentrations of UA (20 and $30 \mathrm{mg} / \mathrm{dL})$ induced a change in cell morphology, although the number of cells remained unaffected. The morphological changes included shrinking of cells, loss of glossy surface, and a darker color. Moreover, we observed an increase in glutamic oxaloacetic transaminase and glutamic pyruvic transaminase expression in cells treated with increasing UA concentrations over extended periods of time. These results suggest that high levels of UA may induce functional damage in hepatocytes (Yang et al., 2015).

Our results suggested that hepatocytes treated with high concentrations of UA for extended periods displayed an increase in apoptosis, as well as 8-OHdG and ROS activities. ROS are continuously generated during respiration. Under normal conditions, ROS production and clearance occurs in dynamic equilibrium; however, factors such as stress induce an oxidantantioxidant imbalance, which leads to the production and accumulation of large amounts of ROS. Slow ROS clearance promotes oxidative stress-induced oxidative damage to biological macromolecules, cellular structures, and DNA (Avery, 2011). In this study, the increase in ROS levels corresponded to the increase in UA levels over time, indicating that UA enhanced oxidative stress in hepatocytes. The results of this study indicated that the presence of UA at concentrations greater than physiological levels induces apoptosis, a form of programmed cell death, in hepatocytes. These results are similar to those obtained by Yu et al. (2010), who reported that UA promotes apoptosis in human umbilical vein endothelial cells. Previous studies have shown that ROS enhances apoptosis by inducing oxidative stress during neuronal injury (Loh et al., 2006). Another study proposed that apoptotic events occurring under high UA levels are dependent on ROS generation (Verzola et al., 2014). Moreover, another study reported that mitochondrial dysfunction results in the loss of CCO, inducing an increase in ROS expression and subsequently triggering the intrinsic apoptotic cascade protein (Circu and Aw, 2010), which is similar to the results of our experiment. Therefore, we concluded that increased apoptosis in hepatocytes may be due to UA-induced accumulation of ROS, resulting in increased oxidative stress in hepatocytes. 8-OHdG is a product of highly mutagenic DNA oxidative damage; moreover, it is widely expressed in the nucleus, mitochondria, and metabolites in eukaryotic cells, and prokaryotic cells. Therefore, it can be used as a marker for the detection of DNA damage (Martin, 2008). In this study, we observed an increase in 8-OHdG expression in hepatocytes treated with increasing levels of UA for greater periods, indicating that UA enhances DNA damage in hepatocytes. Avery (2011) reported that ROS causes DNA damage by inducing oxidative stress via lipid peroxidation. Another study reported that ROS causes oxidative damage to DNA (Oka et al., 2008). Therefore, the increase in 8-OHdG content in the hepatocytes could be attributed to the promotion of DNA oxidative damage by UA-induced ROS.

Our results suggest that the presence of UA can decrease ATP, SDH, and CCO activities 
in the mitochondria of hepatocytes. Mitochondria are the main sites of ATP generation (Kuhlbrandt, 2015). High levels of UA were previously found to induce mitochondrial dysfunction, which may lead to excess ROS generation. This suggested that mitochondrial uncoupling decreases the synthesis of ATP via oxidative phosphorylation (Sánchez-Lozada et al., 2012). Therefore, we hypothesized that the decrease in ATP content in the hepatocyte mitochondria was correlated with mitochondrial uncoupling promoted by UA-induced ROS. SDH maintains the function of the electron transport chain and tricarboxylic acid cycle in the mitochondria. To a certain extent, its vitality reflects the integrity of the mitochondrial membrane and explains the role of the Krebs cycle in energy metabolism. The results of our study suggested that high levels of UA in hepatocytes significantly reduced the SDH activity in the mitochondria, indicating that UA damages the mitochondrial membrane structure and inhibits mitochondrial energy metabolism. $\mathrm{CCO}$ is an essential enzyme that produces a proton gradient for ATP production during mitochondrial oxidative phosphorylation (Yoshikawa et al., 2015). The results of our study suggest that high levels of UA in hepatocytes significantly reduced CCO activity in the mitochondria. A previous study showed that mitochondrial ATP production can be upregulated via positive regulation of $\mathrm{CCO}$ activity, thereby preventing myocardial cell hypoxia (Hayashi et al., 2015), while another study showed that lower $\mathrm{CCO}$ vitality can lead to an increase in ROS generation in the mitochondria (Srinivasan and Avadhani, 2012); these studies support our conclusion that UA-induced oxidative stress in liver mitochondria, and alterations to mitochondrial function, result in cell damage.

\section{CONCLUSIONS}

Overall, our results suggest that UA induces oxidative stress response in the mitochondria, exacerbating mitochondrial dysfunction. This decreases $\mathrm{CCO}$ and SDH expression and reduces ATP production. Reduced secretion of CCO further decreases the ability of mitochondria to generate superoxide, leading to increased production and accumulation of ROS, ultimately promoting hepatocyte apoptosis, mitochondrial dysfunction, and DNA damage.

\section{Conflicts of interest}

The authors declare no conflict of interest.

\section{ACKNOWLEDGMENTS}

Research partially supported by the Natural Science Foundation of the Xinjiang Uygur Autonomous Region, China (\#2015211C011 to L. Ma).

\section{REFERENCES}

Avery SV (2011). Molecular targets of oxidative stress. Biochem. J. 434: 201-210. http://dx.doi.org/10.1042/BJ20101695 Cao YY, Chen ZW, Gao YH, Wang XX, et al. (2015). Exenatide reduces tumor necrosis factor-alpha-induced apoptosis in cardiomyocytes by alleviating mitochondrial dysfunction. Chin. Med. J. 128: 3211-3218. http://dx.doi. org/10.4103/0366-6999.170259

Choi YJ, Shin HS, Choi HS, Park JW, et al. (2014). Uric acid induces fat accumulation via generation of endoplasmic reticulum stress and SREBP-1c activation in hepatocytes. Lab. Invest. 94: 1114-1125. http://dx.doi.org/10.1038/ labinvest.2014.98 
Circu ML and Aw TY (2010). Reactive oxygen species, cellular redox systems, and apoptosis. Free Radic. Biol. Med. 48: 749-762. http://dx.doi.org/10.1016/j.freeradbiomed.2009.12.022

Gao B, Shen L, He KW and Xiao WH (2015). GNRs@SiO ${ }_{2}$-FA in combination with radiotherapy induces the apoptosis of HepG2 cells by modulating the expression of apoptosis-related proteins. Int. J. Mol. Med. 36: 1282-1290.

Glantzounis GK, Tsimoyiannis EC, Kappas AM and Galaris DA (2005). Uric acid and oxidative stress. Curr. Pharm. Des. 11: 4145-4151. http://dx.doi.org/10.2174/138161205774913255

Hayashi T, Asano Y, Shintani Y, Aoyama H, et al. (2015). Higd1a is a positive regulator of cytochrome c oxidase. Proc. Natl. Acad. Sci. USA 112: 1553-1558. http://dx.doi.org/10.1073/pnas.1419767112

Kang DH and Ha SK (2014). Uric acid puzzle: dual role as anti-oxidant and pro-oxidant. Electrolyte Blood Press. 12: 1-6. http://dx.doi.org/10.5049/EBP.2014.12.1.1

Kuhlbrandt W (2015). Structure and function of mitochondrial membrane protein complexes. BMC Biol. 13: 015-0201.

Lanaspa MA, Sanchez-Lozada LG, Choi YJ, Cicerchi C, et al. (2012). Uric acid induces hepatic steatosis by generation of mitochondrial oxidative stress: potential role in fructose-dependent and -independent fatty liver. J. Biol. Chem. 287: 40732-40744. http://dx.doi.org/10.1074/jbc.M112.399899

Li Y, Xu C, Yu C, Xu L, et al. (2009). Association of serum uric acid level with non-alcoholic fatty liver disease: a crosssectional study. J. Hepatol. 50: 1029-1034. http://dx.doi.org/10.1016/j.jhep.2008.11.021

Loh KP, Huang SH, De Silva R, Tan BK, et al. (2006). Oxidative stress: apoptosis in neuronal injury. Curr. Alzheimer Res. 3: 327-337. http://dx.doi.org/10.2174/156720506778249515

Martin LJ (2008). DNA damage and repair: relevance to mechanisms of neurodegeneration. J. Neuropathol. Exp. Neurol. 67: 377-387. http://dx.doi.org/10.1097/NEN.0b013e31816ff780

Oka S, Ohno M, Tsuchimoto D, Sakumi K, et al. (2008). Two distinct pathways of cell death triggered by oxidative damage to nuclear and mitochondrial DNAs. EMBO J. 27: 421-432. http://dx.doi.org/10.1038/sj.emboj.7601975

Port GZ, Oliveira K, Soldera J and Tovo CV (2014). Biochemical nutritional profile of liver cirrhosis patients with hepatocellular carcinoma. Arq. Gastroenterol. 51: 10-15. http://dx.doi.org/10.1590/S0004-28032014000100003

Sánchez-Lozada LG, Lanaspa MA, Cristóbal-García M, García-Arroyo F, et al. (2012). Uric acid-induced endothelial dysfunction is associated with mitochondrial alterations and decreased intracellular ATP concentrations. Nephron, Exp. Nephrol. 121: e71-e78. http://dx.doi.org/10.1159/000345509

Sautin YY, Nakagawa T, Zharikov S and Johnson RJ (2007). Adverse effects of the classic antioxidant uric acid in adipocytes: NADPH oxidase-mediated oxidative/nitrosative stress. Am. J. Physiol. Cell Physiol. 293: C584-C596. http://dx.doi.org/10.1152/ajpcell.00600.2006

Sirota JC, McFann K, Targher G, Johnson RJ, et al. (2013). Elevated serum uric acid levels are associated with nonalcoholic fatty liver disease independently of metabolic syndrome features in the United States: Liver ultrasound data from the National Health and Nutrition Examination Survey. Metabolism 62: 392-399. http://dx.doi.org/10.1016/j. metabol.2012.08.013

Srinivasan S and Avadhani NG (2012). Cytochrome c oxidase dysfunction in oxidative stress. Free Radic. Biol. Med. 53: 1252-1263. http://dx.doi.org/10.1016/j.freeradbiomed.2012.07.021

Verzola D, Ratto E, Villaggio B, Parodi EL, et al. (2014). Uric acid promotes apoptosis in human proximal tubule cells by oxidative stress and the activation of NADPH oxidase NOX 4. PLoS One 9: e115210. http://dx.doi.org/10.1371/ journal.pone. 0115210

Wang A, Liu Q, Ye Y, Wang Y, et al. (2015). Identification of hepatoprotective xanthones from the pericarps of Garcinia mangostana, guided with tert-butyl hydroperoxide induced oxidative injury in HL-7702 cells. Food Funct. 6: 30133021. http://dx.doi.org/10.1039/C5FO00573F

Yang Y, Zhou Y and Ma L (2015). Effects of uric acid on hepatocyte function and oxidative stress. Xinjiang Med. Univ. 38: $1252-1256$.

Yoshikawa S, Shimada A and Shinzawa-Itoh K (2015). Respiratory conservation of energy with dioxygen: cytochrome C oxidase. Met. Ions Life Sci. 15: 89-130.

Yu MA, Sánchez-Lozada LG, Johnson RJ and Kang DH (2010). Oxidative stress with an activation of the renin-angiotensin system in human vascular endothelial cells as a novel mechanism of uric acid-induced endothelial dysfunction. $J$. Hypertens. 28: 1234-1242.

Zhang J-X, Zhang Y-P, Wu Q-N and Chen B (2015). Uric acid induces oxidative stress via an activation of the reninangiotensin system in 3T3-L1 adipocytes. Endocrine 48: 135-142. http://dx.doi.org/10.1007/s12020-014-0239-5 